\title{
Student Motivation in STEM Careers at Three Northwest Universities of Mexico
}

\author{
María Amparo Oliverosㄴ, Lidia Esther Vargas , Benjamín Valdez¹, Eduardo Cabrera², \\ Miguel Schoor ${ }^{1}$, José Luis Arcos ${ }^{1}$
}

${ }^{1}$ Autonomous University of Baja California, Mexicali, México

${ }^{2}$ Polytechnic University of Baja California, Mexicali, México

Email: amparo@uabc.edu.mx

How to cite this paper: Oliveros, M. A., Vargas, L. E., Valdez, B., Cabrera, E., Schoor, M., \& Arcos, J. L. (2016). Student Motivation in STEM Careers at Three Northwest Universities of Mexico. Creative Education, 7, 2829-2835.

http://dx.doi.org/10.4236/ce.2016.718262

Received: October 20, 2016

Accepted: December 18, 2016

Published: December 21, 2016

Copyright $\odot 2016$ by authors and Scientific Research Publishing Inc. This work is licensed under the Creative Commons Attribution International License (CC BY 4.0).

http://creativecommons.org/licenses/by/4.0/

\begin{abstract}
Mexico hosts a large number of modern firms, notably in the sectors of aerospace, automobiles, foods and beverages, which employ high-skilled and well-educated workers. Therefore, Graduates from Science, Technology, Engineering, and Mathematics (STEM) fields are both in high demand in the labor market and among the most highly paid. Even though, 30.9\% of Mexican employers report having faced difficulties finding people with the necessary skills to fill vacancies in STEM areas. Three universities in the northwest region of Mexico conformed a STEM network aiming to promote enrollment, retention and gender equality on STEM careers. An instrument based on Questionnaire ROSE-Q or "Relevance of Science Education" allowed gathering information that allows measuring relevant indicators to support the design of actions and strategies. The project was carried out with funds granted in 2016 from the National Council on Science and Technology (CONACYT). The main indicators impacting the STEM career choice of students are about cultural training, youth identity, and gender equity.
\end{abstract}

\section{Keywords}

Motivation, Engineering Students, Higher Education

\section{Introduction}

The low rate of young people enrolled in the areas of Science, Technology, Engineering and Mathematics (STEM) is a major international challenge. In studies of global innovation, mainly tertiary education, the STEM fields have been identified as a critical determinant in the level of innovation (Soumitra, 2011). In the case of Mexico according to the National Association of Universities and Institutions of Higher Education 
(ANUIES) (2013), only $20 \%$ of young people opt for a STEM career, and with a dropout rate of $50 \%$. The objective of this work is to determine data to understand the factors that define the choice of the young people of STEM careers in three public universities: Autonomous University of Baja California, Polytechnic University of Baja California and University of Sonora Estate.

\section{Theoretical Framework}

\subsection{STEM Model}

The STEM model according to the National Science Foundation (NSF, 2014) of the United States is an attempt to capture the spirit of the education, communities, and the workforce, that include, critical thinking, analysis and teamwork in which students integrate the processes and concepts in the real world, for the development of competencies for the university, work, and life.

At present, the impulse of STEM initiatives has turned into one of the fundamental objectives of the educational planning, not only in countries like United States, United Kingdom or Finland, but also for the whole European Union and various international organizations. Even leading companies in diverse sectors, but overall were linked to the technological field, have joined efforts with public administrations to develop programs or initiatives of technical vocations promotions among the young people (Boe, Henriksen, Lyons, \& Schreiner, 2011).

\subsection{Projected Needs for STEM Professionals in the Future Workforce}

The STEM participation challenge arises not only from falling enrollments in some disciplines, as described above but also from projected needs for increases in the STEM work-force in the future. Projections from some countries indicate that the demand for STEM-educated labor will increase during the years to come, and there is widespread concern that the supply of people educated within STEM will be too small to meet future demands (Bjørnstad, Fredriksen, Gjelsvik, \& Stølen, 2008).

Agree to the report of OECD (2015), Mexico represents the lowest level of the requirements of the labor market with technological activities of high-level. On this data, $30.9 \%$ of Mexicans employers report having faced difficulties to find people with the skills needed to fill the vacancies in STEM areas due to the low levels of innovation in the Mexican economy. Among OECD countries, Mexico has a very low score patent and relevant scientific publications. About the gender gap, although boys and girls have similar skills in math and science, their attitude towards learning and aspirations for the future are markedly different, which has a substantial effect on their decision to continue studies of a higher level and with their choice of career (Archer et al., 2012).

According to research among which stand (Hill, Corbett, \& St. Rose, 2010) has shown that men and women have similar capabilities to study science and technology. The gender gap in the choice of careers seems to emerge from attitudinal and socialization aspects that are different in men and women. It has been mainly investigated the negative attitude of the women that hap-pens by the absence of models of scientists and 
engineers women in education. The didactics and science class environment more appropriate for men are the male vision of science, social and cultural pressure of gender roles on women (Blickenstaff, 2005).

\subsection{STEM as a Tool to Encourage Studies in Engineering}

The OECD, with the purpose to increase the economic development of the country, sets educational policies for Latin America based on the STEM. The model combines a number of different types of content that emphasize educational strategies with the objective of motivate and avoid drop-out of students in engineering. For example, temporary stays in companies for practical application of the knowledge acquired in the university, implementation of experiential workshops, critical reading, debates, panel discussions, critical thinking, fairs and contests of science, clubs, and research networks at the universities, are applied as workshops and talks of successful mentors in the STEM areas. The STEM participation was eliminated.

\section{Methodology}

The applied instrument, Relevance of Science Education Questionnaire ("ROSE-Q"), aims to investigate the intrapersonal and interpersonal factors skills that may influence the choice of STEM courses, consists of open and closed questions (Schreiner \& Sjoberg, 2004). Five questions were chosen that investigate: school of origin, gender, the importance of the academic experience for career choice, perception on the importance that had some people for the career selection and opinion on aspects of daily life as a student. The application of the ROSE-Q questionnaires was carried out to first-year students on STEM careers from three universities, undertaken during the period of the month of May-August of the year 2016. The total enrollment of students in engineering area among three universities was 6064 students, of which 1421 responded or sample of $23 \%$ of entire population.

The key feature of ROSE is to gather and analyses information from the learners about several factors that have a bearing in their attitudes to Science and Technology and their motivation to learn. The purpose of rose is not testing of achievement studies as Trends in International Mathematics and Science Study (TIMMS) or Program for international student assessment (PISA), but rather to address attitudinal and motivational aspects. ROSE is not a procedure for measuring a construct. However, items clusters in this study may emerge from the data analysis, and not from a clear explication of the instrument (Henriksen, Dillon, \& Ryder, 2015).

\section{Results and Discussion}

The results show that the profile of the career choice through the responses of the women students to some of the items of ROSE-Q, which analyzes intrapersonal and interpersonal elements of students of the three participating institutions.

- Average student participation in all universities was $23.4 \%$. UABC with the highest enrolment showed the smallest sample size with $15.2 \%$. On the other side, UES 
sample size went up to $65.4 \%$ as engineering enrolment is the smallest (see Table 1 ).

- It is important to highlight that only $26.6 \%$ of the students surveyed are women enrolled in the STEM areas, so we can observe that there is a gender underrepresentation (see Table 2).

- An $84.4 \%$ of students feel motivated only if they have an interest in the subject, continuing with knowing with certainty that they obtained the correct answer $76.9 \%$. And finally, with $74.2 \%$ the students value classes that include a practical applications of the subject (see Table 3 ).

Table 1. Breakdown of participation of each institution involved in the study.

\begin{tabular}{ccccc}
\hline \multirow{2}{*}{ Institution } & \multicolumn{4}{c}{ Table Column Head } \\
\cline { 2 - 5 } & $\begin{array}{c}\text { Total enrollment at } \\
\text { the moment of study }\end{array}$ & $\begin{array}{c}\text { Engineering } \\
\text { enrollment }\end{array}$ & $\begin{array}{c}\text { Participating } \\
\text { STEM students }\end{array}$ & $\begin{array}{c}\text { Participation } \\
(\%)\end{array}$ \\
\hline UABC & 65,323 & 4,314 & 659 & 15.2 \\
UPBC & 1,472 & 1,342 & 495 & 36.8 \\
UES & 2,021 & 408 & 267 & 65.4 \\
Total & 68,816 & 6,064 & 1,421 & 23.4 \\
\hline
\end{tabular}

Table 2. Students by gender.

\begin{tabular}{ccc}
\hline Gender & $\mathrm{N}$ & $\%$ \\
\hline Female & 378 & 26.6 \\
Male & 1043 & 73.4 \\
Total & 1421 & 100
\end{tabular}

Students surveyed enrolled in the STEM areas.

Table 3. Perception on the importance of the school experience for the career choice.

\begin{tabular}{lccccc}
\hline & \multicolumn{5}{c}{ Value scale (\%) } \\
\cline { 2 - 6 } \multicolumn{1}{c}{ Aspects to be value } & $\begin{array}{c}\text { Not } \\
\text { important }\end{array}$ & $\begin{array}{c}\text { Slightly } \\
\text { important }\end{array}$ & Neutral & Important $\begin{array}{c}\text { Very } \\
\text { important }\end{array}$ \\
\hline Interest in related topics & 0.7 & 1.1 & 13.8 & 34.1 & 50.3 \\
Previous performance in related topics & 2.1 & 3.8 & 24.6 & 42.0 & 27.5 \\
Experiments and laboratory works & 5.5 & 10.1 & 24.1 & 32.7 & 27.5 \\
Fieldwork or excursions & 8.4 & 13.2 & 25.9 & 26.0 & 26.5 \\
Classes that show importance of topic to society & 4.9 & 9.1 & 24.3 & 35.1 & 26.6 \\
Classes that show practical application & 1.9 & 5.1 & 18.8 & 37.5 & 36.7 \\
The use of mathematics in classes & 3.5 & 5.8 & 19.3 & 30.8 & 40.7 \\
Know with certainty that got the correct answer & 2.1 & 3.4 & 17.6 & 33.1 & 43.8 \\
\hline
\end{tabular}

Aspects related to the importance of the education experience for the career choice. 
- In general, students reported with regular and low percentages, the influence that some people had to carry out the election of the career. In the first place, with the highest score, $54.5 \%$ the influence to have had good teachers. In the second place, $53.0 \%$ said that the mother or stepmother, following in $48.9 \%$ the father or stepfather (see Table 4).

- High percentages resulted on comments about aspects of everyday life as student, $96.6 \%$ value their overall experience as students, $96.3 \%$ enjoy the social relationship with classmates, and $84.20 \%$ felt that they could go to the pace of the class. Also, students found better than expected in a $49.8 \%$ interesting contents of the career and $37.5 \%$ the quality of teaching (see Table 5).

Table 4. Perception on the importance that had some people for the election of the career.

\begin{tabular}{|c|c|c|c|c|c|}
\hline \multirow[b]{2}{*}{ Aspects to be value } & \multicolumn{5}{|c|}{ Value scale (\%) } \\
\hline & $\begin{array}{c}\text { Not } \\
\text { important }\end{array}$ & $\begin{array}{c}\text { Slightly } \\
\text { important }\end{array}$ & Neutral & Important & $\begin{array}{c}\text { Very } \\
\text { important }\end{array}$ \\
\hline Mother or stepmother & 16.0 & 10.9 & 19.1 & 16.1 & 37.9 \\
\hline Father of stepfather & 22.3 & 11.2 & 17.6 & 15.5 & 33.4 \\
\hline Good teachers & 12.2 & 9.4 & 22.9 & 29.3 & 26.2 \\
\hline Friends (including boyfriend or girlfriend) & 23.8 & 14.4 & 23.0 & 18.8 & 19.0 \\
\hline Sisters/Brothers and other relatives & 24.1 & 14.6 & 21.7 & 17.2 & 22.3 \\
\hline Guidance counselor at school & 27.9 & 16.3 & 23.4 & 17.9 & 14.4 \\
\hline
\end{tabular}

Aspects related to who support on career choice.

Table 5. Opinion on aspects of everyday life as a student.

\begin{tabular}{lccc}
\hline \multicolumn{1}{c}{ Aspects to be value } & \multicolumn{3}{c}{ Value scale (\%) } \\
\cline { 2 - 4 } & $\begin{array}{c}\text { Worse than } \\
\text { expected }\end{array}$ & $\begin{array}{c}\text { As } \\
\text { expected }\end{array}$ & $\begin{array}{c}\text { Better than } \\
\text { expected }\end{array}$ \\
\hline The overall experience of being a student of this career & 3.4 & 64.9 & 31.7 \\
The social relationship with classmates & 3.7 & 56.3 & 40.0 \\
The quality of teaching & 3.1 & 59.4 & 37.5 \\
How interesting is the content of the career & 2.3 & 47.9 & 49.8 \\
The effort made in the study (worst mean more effort) & 15.8 & 62.8 & 21.4 \\
\hline
\end{tabular}

Aspects related to the importance of everyday life as student for the career choice.

\section{Conclusion}

As a conclusion, we observed that young people more and more are informed at the time of choosing a career, which is very positive since allowing decreasing the rejection to this type of areas. The aspect of support for the career choice highlights the importance of having good teachers and in the second place, the figure of the mother as the primary support for choosing a career in the STEM area. Regarding their everyday life 
as a student, the highest score obtained was to enjoy the company of others and that they felt socially accepted, a valuable data piece to promote the retention, taking into account that they are first-year students.

Finally, the scheme of learning of programs related to the areas of science, technology, engineering, and mathematics. It is recommended to be incorporated into the contents of the study plans to promote them from an early age, to achieve awakening the interest in both sexes. Especially, women have to develop teaching-learning activities under the STEM approach with the purpose of changing their cultural perspective, and try to persuade.

\section{Acknowledgements}

Autonomous University of Baja California (UABC), Polytechnic University of Baja California (UPBC) and University of Sonora Estate (UES) acknowledge the financial support from CONACYT (National Council of Science and Technology of Mexico) through the research program "Redes Temáticas".

\section{Conflict of Interest Declaration}

The authors declare that there is no conflict of interests related with this investigation, the authorship and/or the publication of this paper.

\section{References}

Archer, L., DeWitt, J., Osborne, J., Dillon, J., Willis, B., \& Wong, B. (2012). Science Aspirations, Capital, and Family Habitus: How Families Shape Children's Engagement and Identification with Science. American Educational Research Journal, 49, 881-908.

https://doi.org/10.3102/0002831211433290

Bjørnstad, R., Fredriksen, D., Gjelsvik, M. L., \& Stølen, N. M. (2008). Supply and Demand for Labour According to Education, 1986-2025 (Vol. 2008/29, SSB-Rapport). Statistics Norway.

Blickenstaff, J. (2005). Women and Science Careers: Leaky Pipeline or Gender (Vol. 17). Gender and Education: Taylor \& Francis.

Boe, M. V., Henriksen, E. K., Lyons, T., \& Schreiner, C. (2011). Participation in Science and Technology: Young People's Achievement-Related Choices in Late-Modern Societies. Studies in Science Education, 47, 37-72. https://doi.org/10.1080/03057267.2011.549621

Henriksen, E., Dillon, J., \& Ryder, J. (2015). Understanding Student Participation and Choice in Science and Technology Education. Berlin: Springer.

https://doi.org/10.1007/978-94-007-7793-4

Hill, C., Corbett, C., \& St. Rose, A. (2010). Why So Few? Women in Science, Technology, Engineering, and Mathematics. Washington DC: American Association of University Women.

National Association of Universities and Institutions of Higher Education [ANUIES] (2013). Higher Education Indicators.

http://www.anuies.mx/informacion-y-servicios/informacion-estadistica-de-educacion-superior lanuario-estadistico-de-educacion-superior

National Council on Science and Technology (CONACYT) (2016). http://conacyt.gob.mx/

National Science Board (NSF) (2014). Science and Engineering Indicators 2014. 
https://www.nsf.gov/statistics/seind14/content/etc/nsb1401.pdf

Organization for Economic Cooperation and Development (OECD) (2015). The ABC of Gender in Education.

Schreiner, C., \& Sjoberg, S. (2004). Sowing the Seeds of ROSE Background, Rationale, Questionnaire Development and Data Collection for ROSE. A Comparative Study of Students Views of Science and Science Education. Oslo: Department of Teacher Education and School Development, University of Oslo.

Soumitra, D. (2011). The Global Innovation Index, 2011: Accelerating Growth and Development. https://www.globalinnovationindex.org/userfiles/file/gii-2011 report.pdf

Submit or recommend next manuscript to SCIRP and we will provide best service for you:

Accepting pre-submission inquiries through Email, Facebook, LinkedIn, Twitter, etc.

A wide selection of journals (inclusive of 9 subjects, more than 200 journals)

Providing 24-hour high-quality service

User-friendly online submission system

Fair and swift peer-review system

Efficient typesetting and proofreading procedure

Display of the result of downloads and visits, as well as the number of cited articles

Maximum dissemination of your research work

Submit your manuscript at: http://papersubmission.scirp.org/

Or contact ce@scirp.org 